\title{
Phenotypic and genetic effects of recessive haplotypes on yield, longevity, and fertility
}

\author{
J. B. Cole, ${ }^{1}$ D. J. Null, and P. M. VanRaden \\ Animal Genomics and Improvement Laboratory, Agricultural Research Service, USDA, Beltsville, MD 20705-2350
}

\begin{abstract}
Phenotypes from the August 2015 US national genetic evaluation were used to compute phenotypic effects of 18 recessive haplotypes in Ayrshire $(\mathrm{n}=1)$, Brown Swiss $(\mathrm{n}=5)$, Holstein $(\mathrm{n}=10)$, and Jersey $(\mathrm{n}=2)$ cattle on milk, fat, and protein yields, somatic cell score (SCS), single-trait productive life (PL), daughter pregnancy rate (DPR), heifer conception rate (HCR), and cow conception rate (CCR). The haplotypes evaluated were Ayrshire haplotype 1, Brown Swiss haplotypes 1 and 2, spinal dysmyelination, spinal muscular atrophy, Weaver Syndrome, brachyspina, Holstein cholesterol deficiency, Holstein haplotypes 1 to 5 , bovine leukocyte adhesion deficiency, complex vertebral malformation, mulefoot (syndactyly), and Jersey haplotypes 1 and 2 . When causal variants are unknown and tests are based only on single nucleotide polymorphism haplotypes, it can sometimes be difficult to accurately determine carrier status. For example, 2 Holstein haplotypes for cholesterol deficiency have the same single nucleotide polymorphism genotype, but only one of them carries the causative mutation. Genotyped daughters of carrier bulls included in the analysis ranged from 8 for Weaver Syndrome to 17,869 for Holstein haplotype 3. Lactation records preadjusted for nongenetic factors and direct genomic values (DGV) were used to estimate phenotypic and genetic effects of recessive haplotypes, respectively. We found no phenotypic or genetic differences between carriers and noncarriers of Ayrshire or Brown Swiss defects. Several associations were noted for Holstein haplotypes, including fat and HCR for Holstein haplotype 0 carriers; milk, protein, SCS, PL, and fertility for Holstein haplotype 1; protein, PL, CCR, and HCR for Holstein haplotype 2; milk, protein, and fertility for Holstein haplotype 4; and protein yield and DPR for Holstein haplotype 5. There were no differences among bovine leukocyte adhesion deficiency carriers, but complex vertebral malformation affected fat
\end{abstract}

Received December 17, 2015.

Accepted May 31, 2016.

${ }^{1}$ Corresponding author: john.cole@ars.usda.gov yield and mulefoot carriers had higher SCS and lower PL DGV. Jersey haplotype 1 was not associated with any phenotypic effects, but we noted significant differences among DGV for fat, protein, PL, DPR, CCR, and HCR. Jersey haplotype 2 was associated only with lower phenotypic CCR. Effects of the recessive haplotypes on other traits studied generally were small even when significant. Almost $\$ 11$ million of economic losses per year due to reduced fertility and perinatal calf death in the US population can be avoided by selecting mate pairs that will not produce affected embryos. Carrier animals may continue to be selected if the merit of their favorable alleles exceeds the loss from their recessive alleles, but carrier bulls can be generally avoided without reducing the average genetic merit of the sires available for mating.

Key words: genomic evaluation, phenotypic effects, recessive disorders

\section{INTRODUCTION}

The rapid growth in the number of genotyped dairy cattle, which recently surpassed 1 million in the United States (CDCB, 2015), has resulted in the identification of several recessive disorders (e.g., Adams et al., 2012; Cooper et al., 2013; Daetwyler et al., 2014; McClure et al., 2014) and permitted the determination of carrier status of genotyped animals using haplotypes in place of laboratory tests (Cole et al., 2013). Five haplotypes affecting fertility in Holsteins (HH1-HH5) have been identified using the method of VanRaden et al. (2011b), and the causative variants now are known for HH1 (Adams et al., 2012), HH3 (Daetwyler et al., 2014; McClure et al., 2014), HH4 (Fritz et al., 2013), and HH5 (Schütz et al., 2016). The same method was used to determine carrier status for Holstein haplotypes that track bovine leucocyte adhesion deficiency (BLAD; Shuster et al., 1992), brachyspina (Charlier et al., 2012), complex vertebral malformation (CVM; Agerholm et al., 2001), deficiency of uridine monophosphate synthase (DUMPS; Shanks et al., 1984), and mulefoot (syndactyly; Duchesne et al., 2006); results are now routinely reported by the Council on Dairy 
Cattle Breeding (Reynoldsburg, OH). A new Holstein recessive, cholesterol deficiency (CD), was identified by Kipp et al. (2015), but assignment of carrier status is complicated by the presence of harmful and normal variants that have identical SNP haplotypes with a new mutation in one family member a few generations back. The recent discovery of the causal mutation for the Holstein haplotype for cholesterol deficiency (HCD) in the apolipoprotein $\mathrm{B}(A P O B)$ gene (Charlier, 2016; Menzi et al., 2016; Schütz et al., 2016) has resulted in the development of an exact test for carrier status, which is available from some laboratories and is included on some SNP chips. Haplotype tests are available for Brown Swiss haplotypes 1 and 2 (BH1 and BH2), and the causal variant for $\mathrm{BH} 2$ has been identified in the TUBD1 gene (Schwarzenbacher et al., 2016). Brown Swiss haplotype tests for spinal dysmyelination (SDM; Thomsen et al., 2010), spinal muscular atrophy (SMA; Krebs et al., 2007), and Weaver Syndrome (McClure et al., 2013; Kunz et al., 2016) also are provided, but those tests do not directly include the causative mutation. Causal variants are known for SDM, SMA, and Weaver Syndrome, but the tests currently available on commercial SNP are based on haplotypes. An exact test of the loss-of-function mutation is available for Jersey haplotype 1 (Sonstegard et al., 2013), and a haplotype test is available for Jersey haplotype 2 (VanRaden et al., 2014); a haplotype that affects conception rate in Ayrshires (AH1) also is reported (Cooper et al., 2014). The status of each haplotype is reported for all animals receiving genomic evaluations and that information can be used when making mating and culling decisions. Sonstegard et al. (2013) showed that the concordance of haplotype with gene tests generally was very good, ranging from 94.4 (SDM) to 100\% (DUMPS).

Many of these recent recessives were discovered because no homozygous embryos survive, causing reduced fertility (e.g., VanRaden et al., 2011b; Fritz et al., 2013), but limited information exists in the literature on the effects of recessive disorders on other phenotypes, such as yield and longevity of heterozygous females. Some recessive defects, such as DUMPS and HCD, are known to cause differing levels of orotic acid or cholesterol in the blood or milk when heterozygous, and may cause other phenotypic effects. Hoeschele and Meinert (1990) found that daughters of Brown Swiss bulls carrying the Weaver recessive had higher production than daughters of noncarriers, and carrier cows had significantly higher milk and fat production than noncarriers. A within-family analysis of sons and grandsons of Skokie Sensation Ned, the originator of the DUMPS disorder, found that heterozygotes had significantly higher genetic merit for milk and protein yields and economic merit (Shanks and Greiner, 1992). Powell et al. (1996) reported that daughters of Holstein carrier bulls for BLAD had significantly lower protein yields $(P=0.02)$ and higher protein concentrations $(P=0.10)$ than daughters of noncarriers, but the magnitudes of the differences were small. Nielsen et al. (2003) found that fertility was depressed for Holstein cows carrying CVMaffected calves.

Any recessive which results in the death of calves following their birth and early rearing period, such as bovine hereditary zinc deficiency (Yuzbasiyan-Gurkan and Bartlett, 2006), is particularly problematic because the economic impact is much greater than that of recessives that cause early embryonic loss. Recessives that cause loss later in gestation are also expensive if the cow is culled or the next lactation is delayed. The purpose of the current study was to characterize the phenotypic and genetic effects of 18 recessive disorders in the Ayrshire, Brown Swiss, Holstein, and Jersey breeds on 8 yield and fitness traits in the US dairy cattle population and to estimate economic losses.

\section{MATERIALS AND METHODS}

\section{Data}

The data used in our analysis consisted of phenotypes and direct genomic values (DGV) from the August 2015 US national genetic evaluation for genotyped daughters of carrier bulls for 18 recessive haplotypes. The number of animals included in the analysis ranged from 8 for BHW to 17,869 for HH3. The 8 traits included in this study were milk, fat, and protein yields, SCS, single-trait productive life (PL), daughter pregnancy rate (DPR), heifer conception rate (HCR), and cow conception rate (CCR). Cows had a record in the phenotypic analysis for each lactation in the database for every trait but PL and HCR, which had one (lifetime) value, and only animals with phenotypes for all traits were included in the analysis. Animals had only one record each in the analysis of DGV because cows have only one breeding value for each trait. Genotypes for all cows were imputed to the common set of 60,671 SNP used for US genomic evaluations in August 2015 with findhap.f90 version 3 (VanRaden et al., 2011a). The haplotyping strategy was based on the methods described in detail in VanRaden et al. (2011a) and Sonstegard et al. (2013), and refined as discussed by Null and VanRaden (2016). Those SNP were selected based on performance criteria, such as minor allele frequencies, parent-progeny conflicts, call rates, and correlations with other SNP (Wiggans et al., 2010). Descriptive information for each recessive in this study 
Table 1. Description of the recessive haplotypes evaluated for phenotypic effects on yield, longevity, and fertility

Table 1. Description of the recessive haplotypes evaluated for phenotypic effects on yield, longevity, and fetility

\begin{tabular}{|c|c|c|c|c|c|c|c|c|c|}
\hline Breed $^{1}$ & $\mathrm{Haplo}^{2}$ & OMIA ID ${ }^{3}$ & Functional/gene name ${ }^{4}$ & $\begin{array}{c}\text { Haplotype } \\
\text { frequency }(\%)\end{array}$ & BTA & Location $(\mathrm{bp})^{5}$ & $\operatorname{Timing}^{6}$ & Bulls $^{7}$ & Cows $^{8}$ \\
\hline $\mathrm{AY}$ & AH1 & 001934 & PIRM/UBE3B & 13.0 & 17 & $65,921,497$ & $\mathrm{~W}$ & 15 & 32 \\
\hline \multirow[t]{5}{*}{ BS } & BH1 & 001825 & - & 6.67 & 7 & $42,811,272-47,002,161$ & $\mathrm{E}$ & 42 & 300 \\
\hline & $\mathrm{BH} 2$ & 001939 & TUBD1 & 7.78 & 19 & $10,617,246-11,726,846$ & $\mathrm{~B}, \mathrm{~W}$ & 50 & 508 \\
\hline & BHD & 001247 & $\mathrm{SDM} / S P A S T$ & 2.19 & 11 & $14,742,058$ & $\mathrm{~W}$ & 13 & 97 \\
\hline & BHM & 000939 & SMA/KDSR (FVT1) & 3.61 & 24 & $62,118,139-62,156,760$ & $\mathrm{~W}$ & 17 & 77 \\
\hline & BHW & 000827 & Weaver/PNPLA8 & 1.56 & 4 & $49,616,352-49,738,691$ & $\mathrm{~W}$ & 5 & 8 \\
\hline \multirow[t]{10}{*}{$\mathrm{HO}$} & HCD & 001965 & Cholesterol deficiency / $A P O B$ & 2.5 & 11 & $77,953,380-78,040,118$ & $\mathrm{~W}$ & 334 & 11,333 \\
\hline & HH0 & 000151 & Brachyspina/FANCI & 2.76 & 21 & $21,184,869-21,188,198$ & E, B & 325 & 9,150 \\
\hline & HH1 & 000001 & $A P A F 1$ & 1.92 & 5 & $63,150,400$ & $\mathrm{E}$ & 233 & 5,749 \\
\hline & HH2 & 001823 & - & 1.66 & 1 & $94,860,836-96,553,339$ & $\mathrm{E}$ & 221 & 8,312 \\
\hline & HH3 & 001824 & SMC2 & 2.95 & 8 & $95,410,507$ & $\mathrm{E}$ & 438 & 17,869 \\
\hline & HH4 & 001826 & GART & 0.37 & 1 & $1,277,227$ & $\mathrm{E}$ & 54 & 1,218 \\
\hline & HH5 & 001941 & TFB1M & 2.22 & 9 & $92,350,052-93,910,957$ & $\mathrm{E}$ & 434 & 12,587 \\
\hline & НHB & 000595 & $\mathrm{BLAD} / I T G B 2$ & 0.25 & 1 & $145,119,004$ & $\mathrm{~W}$ & 14 & 131 \\
\hline & $\mathrm{HHC}$ & 001340 & CVM/SLC $35 A 3$ & 1.37 & 3 & $43,412,427$ & E, B & 106 & 1,762 \\
\hline & $\mathrm{HHM}^{9}$ & 000963 & Mulefoot/LRP4 & 0.07 & 15 & $77,663,790-77,701,209$ & $\mathrm{~B}$ & 5 & 36 \\
\hline \multirow[t]{2}{*}{ JE } & JH1 & 001697 & $C W C 15$ & 12.10 & 15 & $15,707,169$ & $\mathrm{E}$ & 344 & 13,300 \\
\hline & JH2 & 001942 & - & 1.3 & 26 & $8,812,759-9,414,082$ & $\mathrm{E}$ & 58 & 1,279 \\
\hline
\end{tabular}

${ }^{1} \mathrm{AY}=$ Ayrshire, BS $=$ Brown Swiss, HO = Holstein, and JE $=$ Jersey.

${ }^{2}$ The recessives analyzed include the fertility haplotypes in each breed; haplotypes for spinal dysmyelination (BHD), spinal muscular atrophy (BHM), and Weaver (BHW) in Brown Swiss; and haplotypes for bovine leukocyte adhesion deficiency (HHB), brachyspina (HH0), complex vertebral malformation (HHC), and mulefoot (syndactyly; HHM) in Holsteins (http://aipl.arsusda.gov/reference/recessive_haplotypes_ARR-G3.html).

${ }^{3}$ Online Mendelian Inheritance in Animals (OMIA) identification number for Bos taurus (National Center for Biotechnology Information species code 9913).

${ }^{4} \mathrm{~A}$ blank value indicates that the functional mutation is not currently known.

${ }^{5}$ When the causal variant is known (e.g., AH1), this is the location of the associated SNP. When a candidate gene is known, but not the causal variant, the location includes the coordinates of that gene. When no causal variant or candidate gene is known, this column contains the coordinates of the haplotype used to track the recessive.

${ }^{6}$ Timing of embryonic loss or calf death for homozygous individuals: $\mathrm{B}=$ calf death at or shortly following birth, $\mathrm{E}=$ embryonic loss or abortion, and $\mathrm{W}=$ calf death is weeks or months following birth. In some cases, losses may occur in more than one time period.

${ }^{7}$ The number of carrier bulls with genotyped daughters that had yield deviations in the August 2015 US national genetic evaluation.

${ }^{8}$ The number of genotyped cows with yield deviations in the August 2015 US national genetic evaluation.

${ }^{9}$ Mulefoot (syndactyly) is not lethal in that it does not actually kill affected calves, but affected animals are always culled and there is a resulting economic loss associated with the condition. 
Table 2. The number of cows and bulls genotyped and the number of SNP markers on the chips used for genotyping

\begin{tabular}{|c|c|c|c|c|c|c|c|c|c|}
\hline \multirow[b]{2}{*}{ Chip name } & \multirow{2}{*}{$\begin{array}{l}\text { SNP } \\
\text { count }\end{array}$} & \multicolumn{2}{|c|}{ Ayrshire } & \multicolumn{2}{|c|}{ Brown Swiss } & \multicolumn{2}{|c|}{ Holstein } & \multicolumn{2}{|c|}{ Jersey } \\
\hline & & Bulls & Cows & Bulls & Cows & Bulls & Cows & Bulls & Cows \\
\hline Imputed genotype & 0 & 0 & 35 & 0 & 332 & 0 & 4,920 & 0 & 340 \\
\hline Illumina BovineSNP50 BeadChip, Version $1^{1}$ & 54,001 & 16 & 0 & 5,359 & 85 & 32,221 & 19,158 & 4,680 & 899 \\
\hline Illumina BovineSNP50 BeadChip, Version $2^{1}$ & 54,609 & 336 & 154 & 8,072 & 118 & 30,231 & 28,478 & 2,613 & 776 \\
\hline Illumina Bovine3K BeadChip ${ }^{1}$ & 2,900 & 0 & 3 & 10 & 455 & 2,094 & 46,241 & 68 & 9,358 \\
\hline Illumina BovineHD BeadChip ${ }^{1}$ & 777,962 & 516 & 9 & 12 & 0 & 969 & 503 & 27 & 16 \\
\hline Affymetrix AxiomBOS1 BeadChip ${ }^{2}$ & 648,875 & 0 & 0 & 0 & 0 & 19 & 0 & 0 & 0 \\
\hline Illumina BovineLD BeadChip ${ }^{1}$ & 6,909 & 6 & 915 & 9 & 517 & 3,182 & 151,566 & 149 & 9,714 \\
\hline GeneSeek Genomic Profiler ${ }^{3}$ & 8,762 & 2 & 54 & 106 & 448 & 9,902 & 38,578 & 1,096 & 12,287 \\
\hline GeneSeek Genomic Profiler-HD ${ }^{3}$ & 77,068 & 371 & 420 & 370 & 153 & 7,545 & 13,551 & 587 & 944 \\
\hline GeneSeek Genomic Profiler-Super LD ${ }^{3}$ & 19,809 & 53 & 332 & 936 & 553 & 20,698 & 56,092 & 2,674 & 16,621 \\
\hline Zoetis Low Density ${ }^{4}$ & 11,410 & 0 & 0 & 18 & 75 & 1,069 & 104,657 & 121 & 9,641 \\
\hline Zoetis Medium Density $^{4}$ & 56,955 & 1 & 559 & 0 & 2 & 491 & 1,756 & 20 & 2 \\
\hline EuroG10K ${ }^{1}$ & 9,072 & 0 & 0 & 0 & 0 & 87 & 692 & 0 & 0 \\
\hline Illumina BovineLD BeadChip. Version $1.1^{1}$ & 6,912 & 0 & 0 & 0 & 14 & 946 & 11,798 & 6 & 1,708 \\
\hline GeneSeek Genomic Profiler LD Version $3^{3}$ & 26,151 & 86 & 637 & 301 & 769 & 22,953 & 56,976 & 3,672 & 19,688 \\
\hline Zoetis Low Density Version $2^{4}$ & 17,619 & 0 & 1 & 8 & 259 & 4,232 & 181,631 & 155 & 12,884 \\
\hline Zoetis Medium Density Version $2^{4}$ & 60,914 & 0 & 0 & 2 & 0 & 349 & 2,143 & 44 & 4 \\
\hline GGP Bovine $150 \mathrm{~K}^{3}$ & 139.480 & 97 & 32 & 364 & 37 & 13.322 & 8,162 & 1.383 & 506 \\
\hline GGP Bovine $7 \mathrm{~K}^{3}$ & 7,083 & 0 & 0 & 0 & 0 & 3 & 376 & 0 & 16 \\
\hline Total & & 1,484 & 3,186 & 15,567 & 3,817 & 727,278 & 150,313 & 17,295 & 95,404 \\
\hline
\end{tabular}

를 ${ }^{2}$ Affymetrix, Santa Clara, CA.

ఏ ${ }^{3}$ Gene Seek, Lincoln, NE.

으 ${ }^{4}$ Zoetis, Florham Park, NJ. 
is provided in Table 1, and Table 2 includes details about the cow and bull genotypes included in the study. Definitions of the SUP haplotypes used in this analysis are provided in Supplemental Table S1 (http://dx.doi. org/10.3168/jds.2015-10777).

Whereas the causal variants are now known for several recessive disorders, and those variants now are present on some of the SNP genotyping chips, many of the recessive tests are still based on haplotypes rather than individual SNP (Table 3). Most of the genotypes in the national dairy database do not include the SNP tests, so haplotype tests must be used until enough data are available to accurately impute carrier status for older genotypes. There also are cases (e.g., HH0) where SNP tests are used, but those test results are not transmitted from the genotyping laboratories to the Council on Dairy Cattle Breeding (Bowie, MD) due to intellectual property agreements. Results from custom assays, such as Sequenom MassARRAY (Agena Bioscience, San Diego, CA) genotypes, used by many research groups, are not part of the national dairy database, either.

\section{Assignment of HCD Carrier Status}

Two variants are unique to the SNP haplotype for HCD in the population, one that includes the harmful variant and one that does not. Both haplotypes share identical SNP genotypes but have different origins, which is similar to variants associated with arachnomelia (Drögemüller et al., 2010) and zinc deficiency-like syndrome (Jung et al., 2014). The haplotype carrying the harmful variant is transmitted by the bull Maughlin Storm (HOCAN000005457798) and his descendants, whereas the nonharmful haplotype is transmitted by Willowholme Mark Anthony (HOCAN000000334489) and his descendants. The nonlethal haplotype actually originated with the bull Fairlea Royal Mark (HOCAN000000299855; Kipp et al., 2015), but that animal is not genotyped in the United States and pedigrees instead are traced back to Anthony. A list of carriers and putatively affected animals was constructed based on genotypes, and pedigrees are then traced back to determine the origin of the recessive haplotypes. Heterozygotes whose pedigrees trace back to Storm, but not Anthony, are coded as 1, indicating that they are known carriers of the harmful allele. Similarly, homozygotes with pedigree paths to Storm but not Anthony are coded as 2, indicating that they are homozygous for the harmful version of the haplotype. Heterozygotes and homozygotes with both Storm and Anthony in their pedigrees are coded as 3 and 4, respectively, indicating that they may be carriers of the harmful haplotype. Animals with incomplete pedigrees are coded as 3 or 4 when their pedigrees do not trace far enough back to determine which haplotype version of the recessive haplotype they carry. Only animals known to carry 0 or 1 copies of the harmful allele (coded 0 or 1 in the haplotype analysis) were included in the analysis of genetic and phenotypic effects. Phenotypes of homozygous recessive animals were not analyzed for HCD effects because they die before any trait other than stillbirth can be measured.

\section{Estimation of Phenotypic and Genetic Effects}

The following fixed effects model was fit to phenotypic and genetic values for all traits using PROC GLM in SAS 9.4 for Linux (SAS Institute Inc., Cary, NC):

$$
\mathrm{y}_{\mathrm{ijk}}=\mu+\text { sire }_{\mathrm{j}}+\text { haplotype }_{\mathrm{k}}+\mathrm{e}_{\mathrm{ijk}},
$$

where $y_{\mathrm{ijk}}$ is the phenotypic value or DGV for any of the 8 traits evaluated for cow $i, \mu$ is the overall mean, sire ${ }_{j}$ is the fixed effect of the cow's sire, haplotype ${ }_{\mathrm{k}}$ is the fixed effect of the haplotype being considered (coded as 0 or 1 copies of the minor allele), and $e_{i j k}$ is the random residual error term. Sire effects were absorbed, and haplotype effects were tested for differences using a $t$ test. Phenotypes were preadjusted for nongenetic factors by subtracting management group, parity-sex, and herd-by-sire effects from each observation. The DGV were calculated as the sum of individual SNP effects from the August 2015 genomic evaluation (Wiggans et al., 2011) plus breed- and trait-specific intercepts (Cole and Null, 2013). A within-trait Bonferroni adjustment was used to correct for multiple comparisons, and significance was declared when $P<0.0028$.

\section{Genetic Merit of Carrier Versus Noncarrier Bulls}

Culling decisions are made based on a combination of predicted genetic merit and recessive carrier status. It is, therefore, desirable to know if carrier bulls are of consistently higher or lower genetic merit than noncarriers. The average genomic PTA for lifetime net merit (NM\$; VanRaden and Cole, 2014) was calculated for the bulls of each breed with semen currently available for purchase (status codes of A, for active AI bulls; F, for foreign-sampled bulls with semen available in the United States; G, for genomically tested bulls at least 12 mo old; and L, for limited-use bulls). These were then compared based on carrier status to determine if carriers or noncarriers have a systematic advantage over other bulls. Averages were tested for differences using a $z$-test within breed. 
Table 3. Availability of SNP tests, the type of test used, the number of genotypes that included haplotype and SNP tests, and SNP genotype frequencies for recessive disorders from the August 2015 evaluation

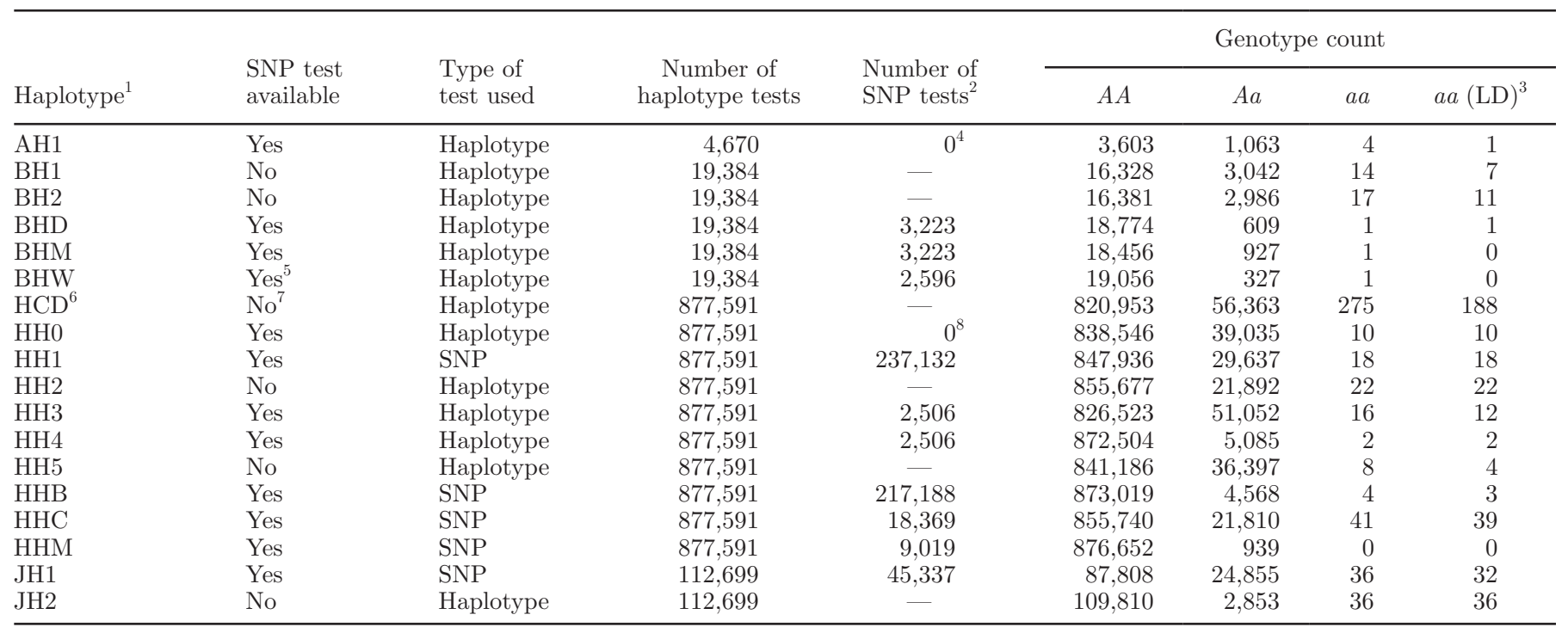

${ }^{1}$ The recessives analyzed include the fertility haplotypes in each breed; haplotypes for spinal muscular atrophy (BHM), spinal dysmyelination (BHD), and Weaver (BHW) in Brown Swiss; and haplotypes for bovine leukocyte adhesion deficiency (HHB), brachyspina (HH0), complex vertebral malformation (HHC), and mulefoot (syndactyly; HHM) in Holsteins (http://aipl.arsusda.gov/reference/recessive_haplotypes_ARR-G3. html).

${ }^{2} \mathrm{~A}$ blank value indicates that the functional mutation is not currently known.

${ }^{3}$ The number of homozygous calls from low-density ( $<30 \mathrm{~K}$ SNP) genotypes.

${ }^{4}$ No genotypes from chips including the AH1 causal SNP were received before the August 2015 genetic evaluation run.

${ }^{5}$ Several SNP associated with Weavers are included on some SNP genotyping chips, including the recent candidate variant reported in the PNPLA8 gene.

${ }^{6}$ The heterozygote counts for HCD include code 3 and 4 animals.

${ }^{7}$ The causal variant for HCD has recently been identified, but test results from SNP genotyping chips are not yet available.

${ }^{8}$ The SNP genotype for HH0 (brachyspina) is not transmitted from the genotyping laboratories to the Council on Dairy Cattle Breeding.

\section{Economic Impact of Recessives}

The economic impact on producers of the recessives carried by each breed was calculated as the product of the total national herd size (9 million), the proportion of the population represented by each breed based on the number of records from cows calving in 2014 included in the national genetic evaluations (CDCB, 2016), and the sum of squared carrier frequencies multiplied by the economic impact of the loss for each recessive. An average value of $\$ 200$ was used for pregnancy loss [A. De Vries (University of Florida, Gainesville), personal communication] and a value of $\$ 342$ was used for lost calves (assumed dead at $21 \mathrm{~d}$ ), which is the average calf value assigned to stillbirths in the lifetime net merit calculations (VanRaden and Cole, 2014) plus $\$ 2$ per day for rearing costs for $21 \mathrm{~d}$. Pregnancy losses are coded E (early pregnancy) in Table 1, and calf losses are coded B (death at or near birth) or W (calf death weeks after birth), and costs were calculated using the latest time of loss for a recessive with effects over multiple time periods. All haplotypes within a breed were assumed independent although, for example, HH2 and HH4 both are located on chromosome 1.

\section{RESULTS AND DISCUSSION}

Not all haplotypes are fatal before or near birth, and small numbers of homozygous genotypes were observed for all recessives studied (Table 3). A substantial number of homozygotes (275) for CD were identified, 188 of those using lower-density SNP genotypes. VanRaden and Null (2015) reported that females in the US homozygous for CD had neither breeding nor lactation records, strongly suggesting that they exited the herd as calves. The number of homozygous genotypes for other lethal haplotypes, such as $\mathrm{HH} 0$ and $\mathrm{JH} 2$, were very small, and most homozygotes are likely to be imputation errors based on low-density genotypes. However, homozygous genotypes also can be the result of imperfect linkage disequilibrium between haplotypes and causal mutations or incomplete penetrance.

The phenotypic and genetic effects of the recessive haplotypes on phenotypic and genetic values of 8 traits 
from heterozygous daughters of heterozygous bulls are shown in Tables 4 and 5 , respectively. $P$-values were adjusted on a within-trait basis to account for multiple comparisons. A significant haplotype effect does not necessarily indicate a causal relationship, and the association of the genotype with trait differences may be due to physical linkage of the recessive with the true causal variant. For example, Hedrick (2013) demonstrated that changes in the frequencies of coat color alleles in mice selected for weight gain were properly attributable to physical linkage of the recessive with the true causal variant, not pleiotropy. It should be possible to test such a hypothesis in the US dairy cattle population once more generations are available to test for linkage decay over time.

\section{Cholesterol Deficiency}

In most cases studied previously, it was straightforward to determine carrier status using haplotype tests. This has not proven to be the case with cholesterol deficiency, making it an excellent example of how to use inconclusive genotypes to identify probable carriers. Cholesterol deficiency was identified recently because farmers in Germany reported problems with calves that suffered from loss of appetite, decreases in BW, and diarrhea that were not responsive to veterinary intervention (Kipp et al., 2015). The haplotype has a higher frequency $(2.5 \%$, based on all known and suspected heterozygotes) than many other recessives that also result in calf deaths (Figure 1), such as CVM (1.37\%) and BLAD (0.25\%). Therefore, it is important that carriers and affected animals be identified as quickly as possible. We identified 56,641 Holsteins as carriers of $\mathrm{HCD}$ in the August 2015 genomic evaluation. Of those animals, 30,928 (54.6\%) were heterozygous for the harmful haplotype (code 1) and parental origin could be determined, $275(0.48 \%)$ were homozygous for the harmful haplotype (code 2), 25,077 (44.2\%) were heterozygous for the recessive haplotype but parental origin could not be determined (code 3), and 358 $(0.63 \%)$ were homozygous for the recessive haplotype but parental origin could not be determined (code 4). Approximately half of the putative carriers and affected animals may carry the normal form of the recessive haplotype, which means that the economic impact of HCD is further increased because some unaffected animals will be culled. A laboratory test now is available for the causal variant in the $A P O B$ gene (Charlier, 2016; Menzi et al., 2016; Schütz et al., 2016), and if the exact test is used rather than the haplotype test fewer noncarriers will be culled.

Hypocholesterolemia is characteristic of CD (Kipp et al., 2015), but the relationship of blood cholesterol levels with milk fat production is not known. Carriers of HCD had significantly higher protein yields $(2.36 \pm$ $0.75 \mathrm{~kg}, P=0$. 0016) than noncarriers. It is not clear how HCD might affect protein yield, and this probably represents a physical linkage of the recessive with the true causal variant effect rather than pleiotropy because Maughlin Storm (HOCAN000005457798), the bull in which the HCD mutation originated, had 2 very good copies of chromosome 11 that were transmitted to his daughters and granddaughters along with HCD. However, HCD carriers had significantly higher genetic merit for fat, protein, SCS, PL, DPR, CCR, and HCR than noncarriers. It is important to note, however, that the magnitude of the effects is small $(<1 \mathrm{~kg}$ of fat and protein and $<1 \%$ of DPR, CCR, and HCR) and may reflect increased power due to a large sample size rather than biologically important differences.

\section{Effects of Other Recessive Haplotypes}

The phenotypic effects of the minor allele for each recessive on the 8 traits included in the analysis are shown in Table 4, and the genetic effects in Table 5. The number of observations $(\mathrm{N})$ is smaller in Table 5 than Table 4 because many cows had more than one lactation record for production and fertility traits, increasing the number of records used, but only one genetic evaluation for each trait. Of the 136 phenotype tests conducted, 4 were significant at the 0.0028 level (Bonferroni-adjusted within trait) or higher, including 2 with fat yield, 1 with protein yield, and 1 with CCR. A total of 35 of 136 DGV effects were different from 0, including 2 for milk, 3 for fat, 6 for protein, 3 for SCS, 5 for PL, 4 for DPR, 5 for CCR, and 7 for HCR. The majority of the significant genetic effects (29 of 35 ) were observed for HO haplotypes, and probably reflect greater statistical power due to large sample sizes rather than differences of great biological importance. The following discussion groups results by breed.

Ayrshire. We found no significant phenotypic or genetic effects on fertility, although Cooper et al. (2014) reported a significant effect on sire conception rate. Although not reflected by the fertility traits included in this analysis, Venhoranta et al. (2014) also reported that AH1 is associated with increased juvenile mortality. The lack of significant effects is probably due to the very limited number of animals (15 carrier bulls with a total of 32 genotyped daughters) available for analysis. Whereas some effects appear to be large, such as the $763.22 \pm 349.59 \mathrm{~kg}$ effect on milk yield, the standard errors also are large, reflecting the limited information available.

Brown Swiss. VanRaden et al. (2011b) reported a negative effect of $\mathrm{BH} 1$ on sire conception rate, whereas 
Table 4. Effect of the minor allele for recessive haplotypes on phenotypes preadjusted for nongenetic factors from heterozygous daughters of heterozygous bulls

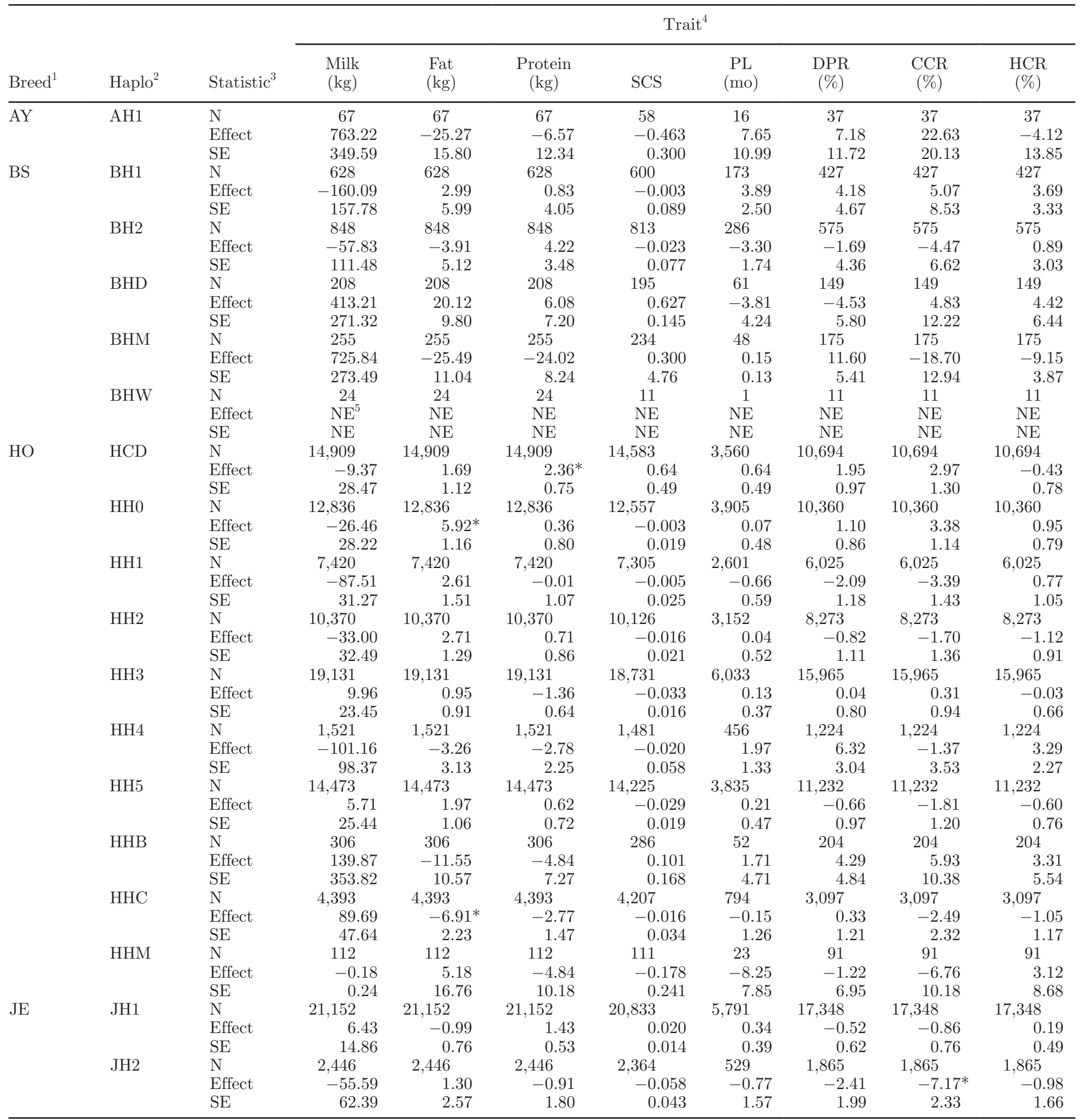

\footnotetext{
${ }^{1} \mathrm{AY}=$ Ayrshire, $\mathrm{BS}=$ Brown Swiss, HO = Holstein, and JE $=$ Jersey.
}

${ }^{2}$ The recessives analyzed include the fertility haplotypes in each breed: haplotypes for spinal muscular atrophy (BHM), spinal dysmyelination (BHD), and Weaver (BHW) in Brown Swiss; and haplotypes for bovine leukocyte adhesion deficiency (HHB), brachyspina (HH0), complex vertebral malformation (HHC), and mulefoot (syndactyly; HHM) in Holsteins (http://aipl.arsusda.gov/reference/recessive_haplotypes_ARR-G3. html).

${ }^{3} \mathrm{n}=$ the number of observations used in the analysis.

${ }^{4} \mathrm{PL}=$ single-trait productive life; $\mathrm{DPR}=$ daughter pregnancy rate; $\mathrm{HCR}=$ heifer conception rate; and $\mathrm{CCR}=$ cow conception rate.

${ }^{5} \mathrm{NE}=$ not estimable.

*Significance at the $5 \%$ level following within-trait Bonferroni adjustment $(P<0.0028)$. 
Table 5. Effect of the minor allele for recessive haplotypes on direct genomic values of heterozygous daughters of heterozygous bulls

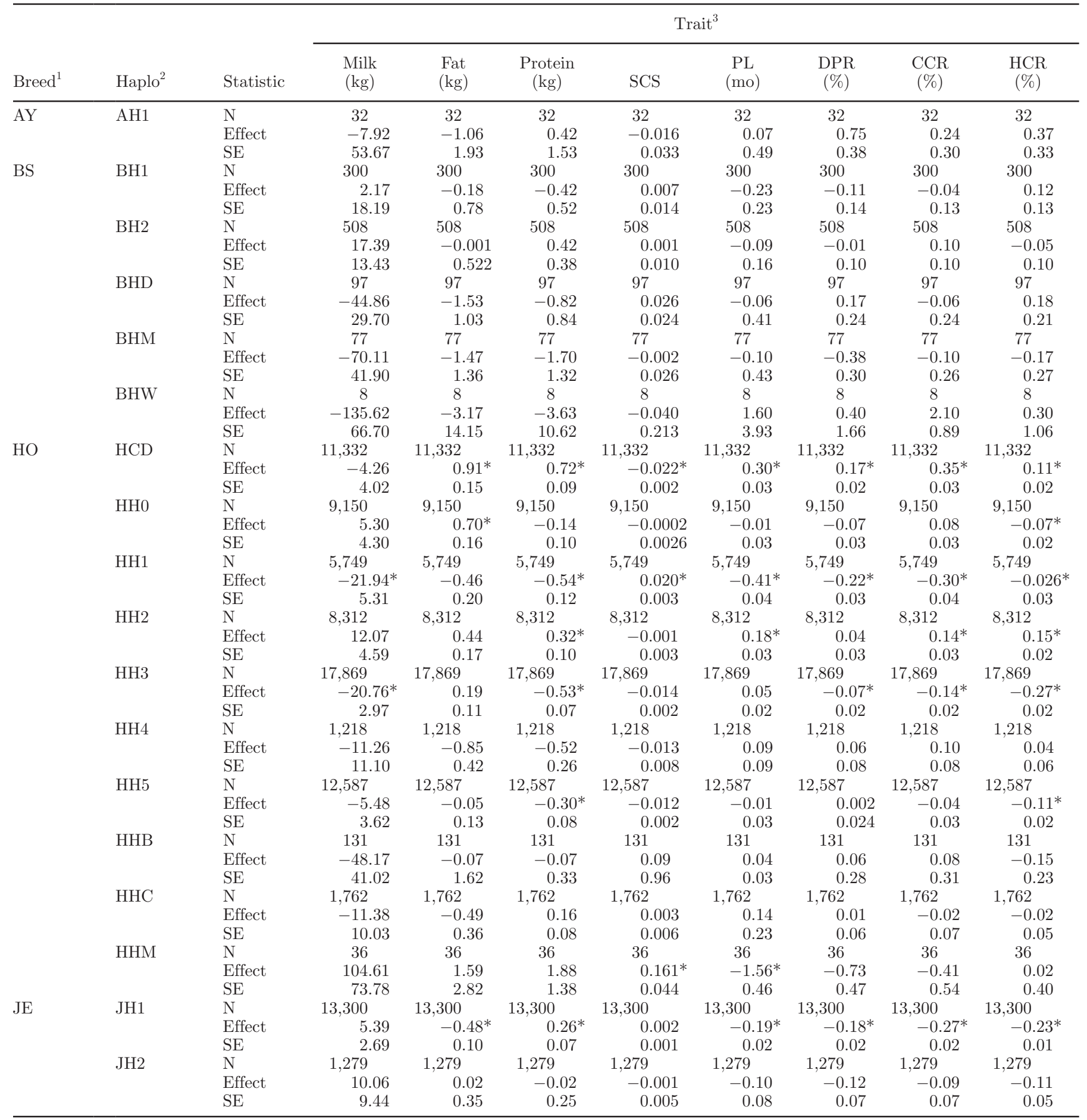

\footnotetext{
${ }^{1} \mathrm{AY}=$ Ayrshire, $\mathrm{BS}=$ Brown Swiss, $\mathrm{HO}=$ Holstein, and JE = Jersey.
}

${ }^{2}$ The recessives analyzed include the fertility haplotypes in each breed; haplotypes for spinal muscular atrophy (BHM), spinal dysmyelination (BHD), and Weaver (BHW) in Brown Swiss; and haplotypes for bovine leukocyte adhesion deficiency (HHB), brachyspina (HH0), complex vertebral malformation (HHC), and mulefoot (syndactyly; HHM) in Holsteins (http://aipl.arsusda.gov/reference/recessive_haplotypes_ARR-G3. html).

${ }^{3} \mathrm{PL}=$ single-trait productive life; $\mathrm{DPR}=$ daughter pregnancy rate; HCR $=$ heifer conception rate; and CCR = cow conception rate.

*Significance at the $5 \%$ level following within-trait Bonferroni adjustment $(P<0.0028)$. 

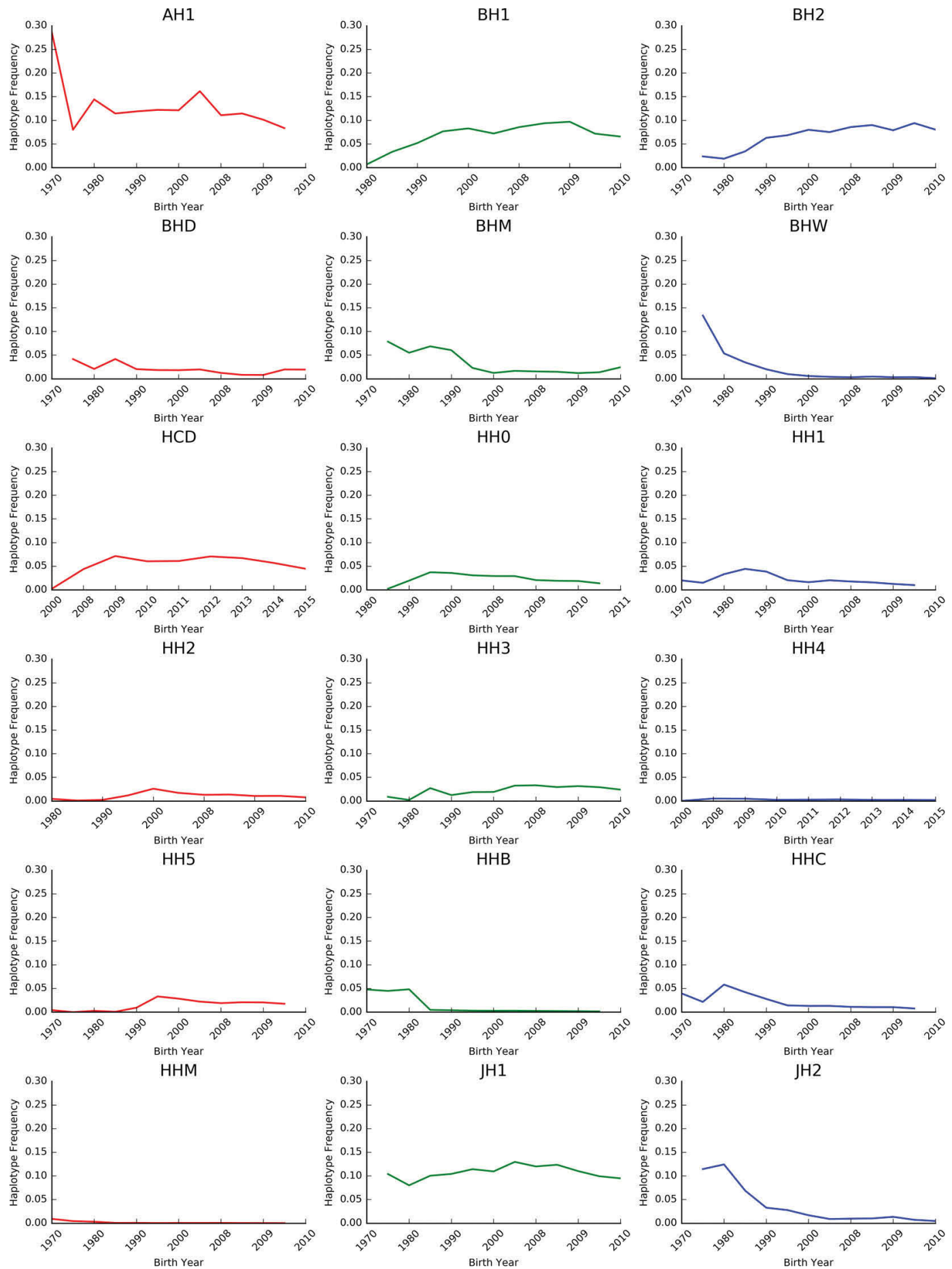

Figure 1. Changes in the frequency of recessive haplotypes. The recessives analyzed include the fertility haplotypes in each breed; haplotypes for spinal dysmyelination (BHD), spinal muscular atrophy (BHM), and Weaver (BHW) in Brown Swiss; and haplotypes for bovine leukocyte adhesion deficiency (HHB), brachyspina (HH0), complex vertebral malformation (HHC), and mulefoot (syndactyly; HHM) in Holsteins (http:// aipl.arsusda.gov/reference/recessive_haplotypes_ARR-G3.html). Color version available online.

the current results show positive but nonsignificant phenotypic effects of BH1 on female fertility. No genetic effects were significant, and estimates were undesirable for DPR and CCR but favorable for HCR. The BH2 haplotype had no significant associations with traits included in our study, although Schwarzenbacher et al. (2012) reported significant phenotypic effects on stillbirth and calf survival for at-risk matings. Neither the 
Table 6. Differences in average lifetime net merit $(\$)$ between bulls that are carriers of at least one recessive disorder and those that are free of known recessives by breed

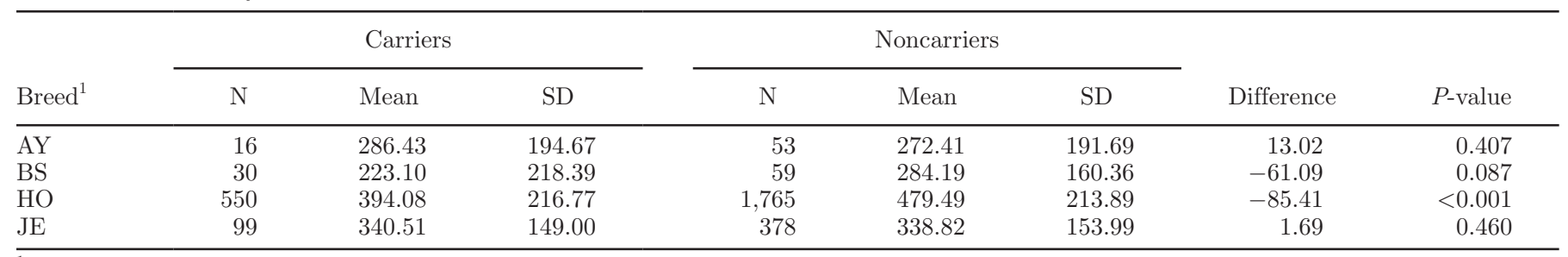

${ }^{1} \mathrm{AY}=$ Ayrshire, $\mathrm{BS}=$ Brown Swiss, $\mathrm{HO}=$ Holstein, and $\mathrm{JE}=$ Jersey.

spinal dysmyelination (BHD) nor the spinal muscular atrophy (BHM) haplotype were associated with phenotypic or genetic differences. No phenotypic effects were estimable for the Weaver haplotype, possibly due to the extremely small sample size $(\mathrm{n}=24)$, and no genetic effect differed from 0. As was the case with Ayrshire, the lack of significant effects may reflect the limited information available.

Holstein. Brachyspina (HHO) carriers had higher phenotypic and genetic fat yields of $5.92 \pm 1.16(P$ $<0.0001)$ and $0.70 \pm 0.16 \mathrm{~kg}(P<0.0001)$, respectively. Direct genomic values for HCR were also lower for HH0 carriers $(-0.07 \pm 0.02 \%)$. There were no phenotypic differences between HH1 carriers and noncarriers, but carriers had significantly lower DGV for milk and protein yields, PL, and fertility, as well as higher (unfavorable) DGV for SCS. In contrast, HH2 carriers had higher genetic merit for protein yield, PL, $\mathrm{CR}$, and HCR than noncarriers. Holstein haplotype 3 carriers had lower milk and protein yields and DPR, CCR, and HCR than noncarriers. No significant results were observed for HH4, which had the fewest observations $(1,218)$ of the Holstein fertility haplotypes. The HH5 carriers had lower DGV for both protein yield and DPR. Whereas HHB carriers did not differ from noncarriers, HHC carriers had lower phenotypes for fat yield $(-6.91 \pm 2.23 \mathrm{~kg} ; P=0.0020)$ than noncarriers. Mulefoot (HHM) carriers had higher SCS (0.161 \pm $0.044 ; P=0.0009)$ and lower PL $(-1.56 \pm 0.46 \mathrm{mo} ; P$ $=0.0018) \mathrm{DGV}$ than noncarriers. It was expected that carriers of HH1 to HH5 would have lower fertility than noncarriers because those haplotypes were identified based, in part, on their effects on fertility. This was the case for all significant CCR, HCR, and DPR effects with the exception of HH2 carriers, which had higher DGV for CCR and DPR.

Jersey. The JH1 haplotype was not associated with any phenotypic effects, but we found significant differences among DGV for fat, protein, PL, DPR, CCR, and HCR. All fertility effects were undesirable, which is consistent with the reduction in sire conception rate associated with JH1 described by Sonstegard et al. (2013). The JH2 haplotype was associated with sig- nificantly lower phenotypic CCR $(-7.17 \pm 2.33 \%, P=$ 0.0022 ), which is consistent with the significant effect on sire conception rate reported by VanRaden et al. (2014).

\section{Genetic Merit of Carrier Versus Noncarrier Bulls}

Bulls that were carriers of at least one recessive had higher average NM $\$$ (VanRaden and Cole, 2014) than noncarriers in the Ayrshire and Jersey breeds, but the differences were not significant (Table 6). Brown Swiss and Holstein carriers had genomic PTA for NM\$ that were $\$ 61.09(P=0.087)$ and $\$ 85.41(P<0.001)$ lower than noncarriers. The differences between Brown Swiss and Holstein bulls may reflect variation in sample size or random differences between birth year cohorts. These results suggest that the use of only noncarrier bulls in breeding programs would not affect the overall genetic trend in the population, but would require using substantially fewer bulls. This may be undesirable because it could result in higher rates of inbreeding.

\section{Economic Impact of Recessives}

Total annual losses across all 4 breeds were estimated as $\$ 10,743,308$. The majority of losses $(\$ 7,500,265)$ were attributable to Holstein, with smaller losses for Ayrshire $(\$ 109,238)$, Brown Swiss $(\$ 233,414)$, and Jersey $(\$ 2,900,390)$. The costliest recessives in each breed were $\mathrm{AH} 1, \mathrm{BH} 2, \mathrm{JH} 1$, and $\mathrm{HH} 0$. In Holsteins, HCD $(\$ 1,696,555)$ and HH3 $(\$ 1,381,452)$ had somewhat lower values than $\mathrm{HH} 0$, the former because of a lower carrier frequency and the latter due to losses occurring earlier in pregnancy. Average losses for animals of each breed were $\$ 5.77, \$ 3.65, \$ 0.94$, and $\$ 2.96$ in Ayrshire, Brown Swiss, Holstein, and Jersey, respectively, which represent the economic impact of genetic load as it affects fertility and perinatal mortality (Supplemental Table S2; http://dx.doi.org/10.3168/jds.2015-10777). However, these results underestimate the total effect of recessives in Holstein, Brown Swiss, and Jersey because there are large populations of those breeds in other countries that use semen from US bulls. The $\$ 342$ 
value used for calf deaths likely is an underestimate of actual losses because it assumes that matings are made at random, rather than considering breeding values and other selection criteria, and does not include labor and veterinary costs associated with treatment of sick calves.

\section{Management of Carriers in the Population}

Each human genome contains approximately 100 lossof-function mutations, including about 20 genes that are completely inactivated (MacArthur et al., 2012), and the total is probably similar for cattle. In the current study, no bull or cow carried copies of more than 5 recessive haplotypes, and most animals carried no copies of any harmful haplotypes (Figure 2). The birth year, number of sons and grandsons in AI, and number of daughters and granddaughters for the founder bull of each recessive are shown in Table 7. Most mutations were spread throughout the population because the founder sired many daughters directly, and then the founder's sons provided many granddaughters. Popular sire effects can be amplified when a bull is heavily used in a small population. For example, Selwood Betty's Commander (AYUSA000000117936), the source of the AH1 haplotype, produced 4,747 daughters and 23,964 granddaughters in a small breed (Ayrshire, with 5,405 cows on milk recording born in 2015).

It is easy to reduce the frequency of a deleterious allele in a population under selection, but is extremely difficult to eliminate it entirely from the population (e.g., Lush, 1945). Known carriers may be removed from the population, but in practice it is more common to avoid carrier-to-carrier matings because carrier
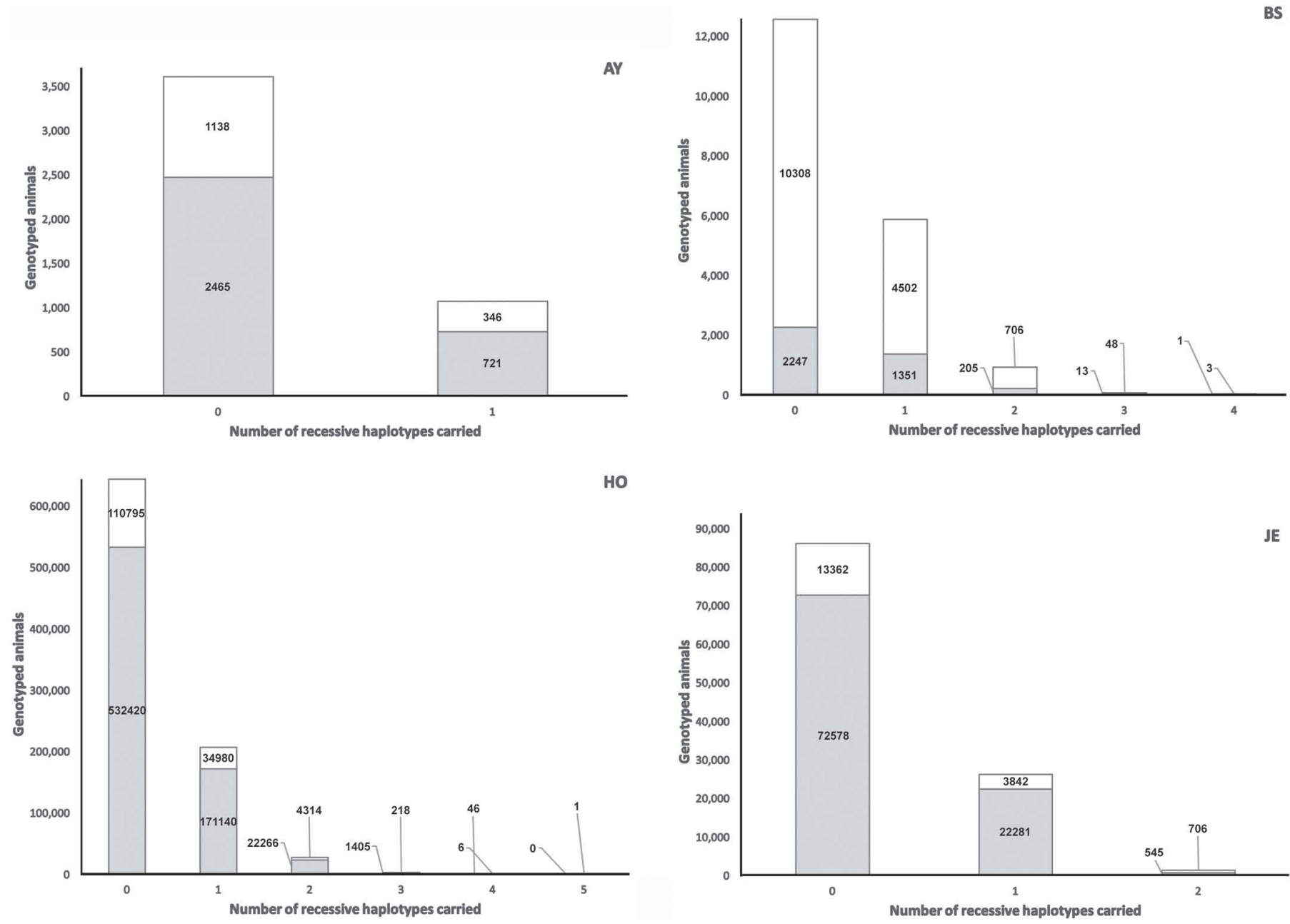

Figure 2. Number of copies of recessive haplotypes carried by genotyped bulls (white bars) and cows (gray bars) of the Ayrshire (AY), Brown Swiss (BS), Holstein (HO), and Jersey (JE) breeds in the US national dairy database. Counts of bulls (upper number) and cows (lower number) are shown for bars that are too small to appear in the figure. 
Table 7. The earliest genotyped ancestor bulls for each recessive haplotype, and the number of daughters, granddaughters, sons, and grandsons in each animal's pedigree in the US national dairy database

\begin{tabular}{|c|c|c|c|c|c|c|c|c|}
\hline Breed & Haplo $^{1}$ & $\begin{array}{l}\text { Earliest genotyped } \\
\text { ancestor name }\end{array}$ & $\begin{array}{l}\text { Earliest genotyped } \\
\text { ancestor identification }\end{array}$ & $\begin{array}{l}\text { Birth } \\
\text { year }\end{array}$ & Daughters & $\begin{array}{l}\text { Grand- } \\
\text { daughters }\end{array}$ & Sons & $\begin{array}{l}\text { Grand- } \\
\text { sons }\end{array}$ \\
\hline $\mathrm{AY}$ & $\mathrm{AH} 1$ & $\begin{array}{l}\text { Selwood Betty's } \\
\text { Commander }\end{array}$ & AYUSA000000117936 & 1953 & 4,747 & 23,964 & 30 & 125 \\
\hline & $\mathrm{BH} 2$ & Rancho Rustic My Design & BSUSA000000144488 & 1963 & 532 & 1,570 & 2 & 16 \\
\hline & $\mathrm{BHD}$ & $\begin{array}{l}\text { White Cloud Jason's } \\
\text { Elegant }\end{array}$ & BSUSA000000148551 & 1966 & 2,194 & 20,810 & 33 & 80 \\
\hline & BHW & Autumn Sun & BSDEU000803611398 & 1951 & 662 & 3,565 & 6 & 8 \\
\hline \multirow[t]{5}{*}{$\mathrm{HO}$} & HCD & Maughlin Storm $^{2}$ & HOCAN000005457798 & 1991 & 14,466 & 143,829 & 112 & 1,080 \\
\hline & HH0 & Sweet-Haven Tradition & HOUSA000001682485 & 1974 & 17,342 & 227,064 & 573 & 1,446 \\
\hline & HH1 & $\begin{array}{l}\text { Pawnee Farm Arlinda } \\
\text { Chief }\end{array}$ & HOUSA000001427381 & 1962 & 16,367 & 528,383 & 472 & 3,941 \\
\hline & HH2 & $\begin{array}{l}\text { Willowholme Mark } \\
\text { Anthony }\end{array}$ & HOCAN000000334489 & 1975 & 1,312 & 2,258 & 9 & 20 \\
\hline & HHM & Gar-Bar-Dale Burke Kate & HOUSA000001410387 & 1961 & 5,508 & 11,848 & 14 & 6 \\
\hline \multirow[t]{2}{*}{ JE } & JH1 & Observer Chocolate Soldier & JEUSA000000596832 & 1962 & 1,458 & 58,841 & 47 & 251 \\
\hline & JH2 & S.S. Quicksilver ff Fallneva & JEUSA000000593883 & 1960 & 3,754 & 58,047 & 52 & 213 \\
\hline
\end{tabular}

${ }^{1}$ The recessives analyzed include the fertility haplotypes in each breed; haplotypes for spinal muscular atrophy (BHM), spinal dysmyelination (BHD), and Weaver (BHW) in Brown Swiss; and haplotypes for bovine leukocyte adhesion deficiency (HHB), brachyspina (HH0), complex vertebral malformation (HHC), and mulefoot (syndactyly; HHM) in Holsteins (http://aipl.arsusda.gov/reference/recessive_haplotypes_ARR-G3. html).

${ }^{2}$ Maughlin Storm is the earliest genotyped carrier of the HCD mutation but may not be the founder. The original mutation may have occurred in a nongenotyped female ancestor.

${ }^{3}$ Besne Buck is the earliest genotyped carrier of the HH4 mutation but may not be the founder. The original mutation may have occurred in a nongenotyped female ancestor.

bulls may have high genetic merit for economically important traits. The results in Table 6 suggest that the complete avoidance of carrier bulls could reduce the frequencies of the recessives studies without major effects on genetic trend, but this would require coordinated action by cattle breeders that seems unlikely. Segelke et al. (2016) recently suggested that selection of cows on an index including haplotypes of interest and bulls on breeding values can be used to balance selection for (or against) specific alleles with genetic gain, and Cole (2015) has demonstrated a strategy for mate allocation that can accommodate many recessives simultaneously. Dairy farmers are unlikely to completely avoid the use of carriers, thus the inclusion of recessives in selection programs is needed to ensure that harmful allele frequencies remain low.

\section{CONCLUSIONS}

Effects of the recessive haplotypes on other traits studied were generally small even when significant. Almost $\$ 11$ million of economic losses due to reduced fertility and perinatal calf death could be avoided by selecting mate pairs that will not produce affected embryos. Carrier animals may continue to be selected if the merit of their favorable alleles exceeds the loss from their recessive alleles, but carrier bulls can be generally avoided without reducing the average genetic merit of the sires available for mating.

\section{ACKNOWLEDGMENTS}

Three anonymous reviewers are thanked for their valuable comments on the manuscript. The Council on Dairy Cattle Breeding (Reynoldsburg, $\mathrm{OH}$ ) and the Cooperative Dairy DNA Repository (Columbia, MO) are acknowledged for providing data used in this study. The authors were supported by appropriated project 1265-31000-096-00, "Improving Genetic Predictions in Dairy Animals Using Phenotypic and Genomic Information," of the Agricultural Research Service of the USDA. Mention of trade names or commercial products in this article is solely for the purpose of providing specific information and does not imply recommendation or endorsement by the USDA. The USDA is an equal opportunity provider and employer. 


\section{REFERENCES}

Adams, H. A., T. Sonstegard, P. M. VanRaden, D. J. Null, C. Van Tassell, and H. Lewin. 2012. Identification of a nonsense mutation in APAF1 that is causal for a decrease in reproductive efficiency in dairy cattle. Abstract P0555 in Proc. Plant Anim. Genome XX Conf. San Diego, CA.

Agerholm, J. S., C. Bendixen, O. Andersen, and J. Arnbjerg. 2001. Complex vertebral malformation in Holstein calves. J. Vet. Diagn. Invest. 13:283-289.

CDCB. 2015. Genotype counts by chip type, breed code, and sex code in database as of 2015-11-15. Accessed Dec. 10, 2015. https:// www.cdcb.us/Genotype/cur_freq.html.

CDCB. 2016. State and national standardized lactation averages by breed for cows calving in 2014 (DHI Report K-2). Accessed Mar. 28, 2016. https://www.cdcb.us/publish/dhi/current/lax.html.

Charlier, C. 2016. The role of mobile genetic elements in the bovine genome. Abstract W636 in Proc. Plant Anim. Genome XXIV Conf. San Diego, CA.

Charlier, C., J. S. Agerholm, W. Coppieters, P. Karlskov-Mortensen, W. Li, G. de Jong, C. Fasquelle, L. Karim, S. Cirera, N. Cambisano, N. Ahariz, E. Mullaart, M. Georges, and M. Fredholm. 2012. A deletion in the bovine FANCI gene compromises fertility by causing fetal death and brachyspina. PLoS ONE 7:e43085.

Cole, J. B. 2015. A simple strategy for managing many recessive disorders in a dairy cattle breeding program. Genet. Sel. Evol. 47:94. http://dx.doi.org/10.1186/s12711-015-0174-9.

Cole, J. B., and D. J. Null. 2013. Visualization of the transmission of direct genomic values for paternal and maternal chromosomes for fifteen traits in U.S. Brown Swiss, Holstein, and Jersey cattle. J. Dairy Sci. 96:2713-2726.

Cole, J. B., P. M. VanRaden, D. J. Null, J. L. Hutchison, T. A. Cooper, and S. M. Hubbard. 2013. AIP Research Report GENOMIC3: Haplotype tests for recessive disorders that affect fertility and other traits. Accessed Aug. 11, 2015. http://aipl.arsusda.gov/ reference/recessive_haplotypes_ARR-G3.html.

Cooper, T. A., G. R. Wiggans, D. J. Null, J. L. Hutchison, and J. B. Cole. 2014. Genomic evaluation, breed identification, and discovery of a haplotype affecting fertility for Ayrshire dairy cattle. J. Dairy Sci. 97:3878-3882.

Cooper, T. A., G. R. Wiggans, D. J. Null, and J. L. Hutchison. 2013. Genomic evaluation and identification of a haplotype affecting fertility for Ayrshire dairy cattle. J. Dairy Sci. 96(E-Suppl.1):74. (Abstr.)

Daetwyler, H. D., A. Capitan, H. Pausch, P. Stothard, R. van Binsbergen, R. F. Brøndum, X. Liao, A. Djari, S. C. Rodriguez, C. Grohs, D. Esquerré, O. Bouchez, M.-N. Rossignol, C. Klopp, D. Rocha, S. Fritz, A. Eggen, P. J. Bowman, D. Coote, A. J. Chamberlain, C. Anderson, C. P. Van Tassell, I. Hulsegge, M. E. Goddard, B. Guldbrandtsen, M. S. Lund, R. F. Veerkamp, D. A. Boichard, R. Fries, and B. J. Hayes. 2014. Whole-genome sequencing of 234 bulls facilitates mapping of monogenic and complex traits in cattle. Nat. Genet. 46:858-865.

Drögemüller, C., J. Tetens, S. Sigurdsson, A. Gentile, S. Testoni, K. Lindblad-Toh, and T. Leeb. 2010. Identification of the bovine arachnomelia mutation by massively parallel sequencing implicates sulfite oxidase $(S U O X)$ in bone development. PLoS Genet. 6:e1001079. http://dx.doi.org/10.1371/journal.pgen.1001079.

Duchesne, A., M. Gautier, S. Chadi, C. Grohs, S. Floriot, Y. Gallard, G. Caste, A. Ducos, and A. Eggen. 2006. Identification of a doublet missense substitution in the bovine LRP 4 gene as a candidate causal mutation for syndactyly in Holstein cattle. Genomics 88:610-621.

Fritz, S., A. Capitan, A. Djari, S. C. Rodriguez, A. Barbat, A. Baur, C. Grohs, B. Weiss, M. Boussaha, D. Esquerré, C. Klopp, D. Rocha, and D. Boichard. 2013. Detection of haplotypes associated with prenatal death in dairy cattle and identification of deleterious mutations in GART, SHBG and SLC37A2. PLoS ONE 8:e65550.

Hedrick, P. W. 2013. Coat colour in mouse populations selected for weight gain: support for hitchhiking, not pleiotropy. Genet. Res. (Camb.) 95:4-13.
Hoeschele, I., and T. R. Meinert. 1990. Association of genetic defects with yield and type traits: The weaver locus effect on yield. J. Dairy Sci. 73:2503-2515.

Jung, S., H. Pausch, M. C. Langenmayer, H. Schwarzenbacher, M. Majzoub-Altweck, N. S. Gollnick, and R. Fries. 2014. A nonsense mutation in $P L D_{4}$ is associated with a zinc deficiency-like syndrome in Fleckvieh cattle. BMC Genomics 15:623.

Kipp, S., D. Segelke, S. Schierenbeck, F. Reinhardt, R. Reents, C. Wurmser, H. Pausch, R. Fries, G. Thaller, J. Tetens, J. Pott, M Piechotta, and W. Grünberg. 2015. A new Holstein haplotype affecting calf survival. Interbull Bull. 49:49-53.

Krebs, S., I. Medugorac, S. Röther, K. Strässer, and M. Förster. 2007. A missense mutation in the 3-ketodihydrosphingosine reductase FVT1 as candidate causal mutation for bovine spinal muscular atrophy. Proc. Natl. Acad. Sci. USA 104:6746-6751.

Kunz, E., S. Rothammer, H. Pausch, H. Schwarzenbacher, F. R. Seefried, K. Matiasek, D. Seichter, I. Russ, R. Fries, and I. Medugorac. 2016. Confirmation of a non-synonymous SNP in PNPLA8 as a candidate causal mutation for Weaver syndrome in Brown Swiss cattle. Genet. Sel. Evol. 48:21-34.

Lush, J. L. 1945. Animal Breeding Plans, 3rd Ed. Iowa State College Press, Ames.

MacArthur, D. G., S. Balasubramanian, A. Frankish, N. Huang, J. Morris, K. Walter, L. Jostins, L. Habegger, J. K. Pickrell, S. B. Montgomery, and C. A. Albers. 2012. A systematic survey of loss-of-function variants in human protein-coding genes. Science 335:823-828

McClure, M., E. Kim, D. Bickhart, D. Null, T. Cooper, J. Cole, G. Wiggans, P. Ajmone-Marsan, L. Colli, E. Santus, G. E. Liu, S. Schroeder, L. Matukumalli, C. Van Tassell, and T. Sonstegard. 2013. Fine mapping for Weaver Syndrome in Brown Swiss cattle and the identification of 41 concordant mutations across NRCAM, PNPLA 8 and CTTNBP2. PLOS ONE 8:e59251.

McClure, M. C., D. Bickhart, D. Null, P. VanRaden, L. Xu, G. Wiggans, G. Liu, S. Schroeder, J. Glasscock, J. Armstrong, J. B. Cole, C. P. Van Tassell, and T. S. Sonstegard. 2014. Bovine exome sequence analysis and targeted SNP genotyping of recessive fertility defects BH1, HH2, and $\mathrm{HH} 3$ reveal causative mutation in SMC2 for HH3. PLoS ONE 9:e92769.

Menzi, F., N. Besuchet-Schmutz, M. Fragnière, S. Hofstetter, V. Jagannathan, T. Mock, A. Raemy, E. Studer, K. Mehinagic, N. Regenscheit, M. Meylan, F. Schmitz-Hsu, and C. Drögemüller. 2016. A transposable element insertion in APOB causes cholesterol deficiency in Holstein cattle. Anim. Genet. 47:253-257.

Nielsen, U. S., G. P. Aamand, O. Andersen, C. Bendixen, V. H. Nielsen, and J. S. Agerholm. 2003. Effects of complex vertebral malformation on fertility traits in Holstein cattle. Livest. Prod. Sci. 79:233-238

Null, D., and P. VanRaden. 2016. April Changes: Mutations in HCD and in BH2. Accessed May 10, 2016. https://www.cdcb.us/ reference/changes/eval1604.htm.

Powell, R. L., H. D. Norman, and C. M. Cowan. 1996. Relationship of bovine leukocyte adhesion deficiency with genetic merit for performance traits. J. Dairy Sci. 79:895-899.

Schütz, E., C. Wehrhahn, M. Wanjek, R. Bortfeld, W. E. Wemheuer, J. Beck, and B. Brenig. 2016. The Holstein Friesian lethal haplotype 5 (HH5) results from a complete deletion of TFB1M and cholesterol deficiency (CDH) from an ERV-(LTR) insertion into the coding region of APOB. PLoS ONE 11:e0154602.

Schwarzenbacher, H., J. Burgstaller, F. R. Seefried, C. Wurmser, M. Hilbe, S. Jung, C. Fuerst, N. Dinhopl, H. Weissenböck, B. FuerstWaltl, M. Dolezal, R. Winkler, O. Grueter, U. Bleul, T. Wittek, R. Fries, and H. Pausch. 2016. A missense mutation in TUBD1 is associated with high juvenile mortality in Braunvieh and Fleckvieh cattle. BMC Genomics 17:400. http://dx.doi.org/10.1186/s12864$016-2742-y$.

Schwarzenbacher, H., C. Fuerst, B. Fuerst-Waltl, and M. Dolezal. 2012. A genome-wide search for harmful recessive haplotypes in Brown Swiss and Fleckvieh cattle. Page 171 in Eur. Fed. Anim. Sci. (EAAP) Ann. Meet. Aug. 28. Wageningen Academic Publishers, Wageningen, the Netherlands. 
Segelke, D., H. Täubert, F. Reinhardt, and G. Thaller. 2016. Considering genetic characteristics in German Holstein breeding programs. J. Dairy Sci. 99:458-467. http://dx.doi.org/10.3168/jds.2015-9764.

Shanks, R. D., D. B. Dombrowski, G. W. Harpestad, and J. L. Robinson. 1984. Inheritance of UMP synthase in dairy cattle. J. Hered. 75:337-340.

Shanks, R. D., and M. M. Greiner. 1992. Relationship between genetic merit of Holstein bulls and deficiency of uridine- 5 '-monophosphate synthase. J. Dairy Sci. 75:2023-2029.

Shuster, D. E., M. E. Kehrli Jr., M. R. Ackermann, and R. O. Gilbert. 1992. Identification and prevalence of a genetic defect that causes leukocyte adhesion deficiency in Holstein cattle. Proc. Natl. Acad. Sci. USA 89:9225-9229.

Sonstegard, T. S., J. B. Cole, P. M. VanRaden, C. P. Van Tassell, D. J. Null, S. G. Schroeder, D. Bickhart, and M. C. McClure. 2013. Identification of a nonsense mutation in $C W C 15$ associated with decreased reproductive efficiency in Jersey cattle. PLoS ONE 8:e54872.

Thomsen, B., P. H. Nissen, J. S. Agerholm, and C. Bendixen. 2010. Congenital bovine spinal dysmyelination is caused by a missense mutation in the SPAST gene. Neurogenetics 11:175-183.

VanRaden, P., and D. Null. 2015 Holstein haplotype for cholesterol deficiency (HCD). Accessed Mar. 28, 2016. https://www.cdcb.us/ reference/changes/HCD_inheritance.pdf.

VanRaden, P., D. Null, J. Hutchison, D. Bickhart, and S. Schroeder. 2014. Jersey haplotype 2 (JH2). Changes to evaluation system (August 2014). Accessed Aug. 12, 2015. https://www.cdcb.us/ reference/changes/eval1408.htm.
VanRaden, P. M., and J. B. Cole. 2014. AIP Research Report NM\$5: Net merit as a measure of lifetime profit: 2014 revision. Accessed Mar. 25, 2016. http://aipl.arsusda.gov/reference/nmcalc-2014. htm.

VanRaden, P. M., J. R. O'Connell, G. R. Wiggans, and K. A. Weigel. 2011a. Genomic evaluations with many more genotypes. Genet. Sel. Evol. 43:10.

VanRaden, P. M., K. M. Olson, D. J. Null, and J. L. Hutchison. 2011b. Harmful recessive effects on fertility detected by absence of homozygous haplotypes. J. Dairy Sci. 94:6153-6161.

Venhoranta, H., H. Pausch, K. Flisikowski, C. Wurmser, J. Taponen, H. Rautala, A. Kind, A. Schnieke, R. Fries, H. Lohi, and M. Andersson. 2014. In frame exon skipping in UBE3B is associated with developmental disorders and increased mortality in cattle. BMC Genomics 15:890.

Wiggans, G. R., P. M. VanRaden, L. R. Bacheller, M. E. Tooker, J. L. Hutchison, T. A. Cooper, and T. S. Sonstegard. 2010. Selection and management of DNA markers for use in genomic evaluation. J. Dairy Sci. 93:2287-2292.

Wiggans, G. R., P. M. VanRaden, and T. A. Cooper. 2011. The genomic evaluation system in the United States: Past, present, future. J. Dairy Sci. 94:3202-3211.

Yuzbasiyan-Gurkan, V., and E. Bartlett. 2006. Identification of a unique splice site variant in SLC39A4 in bovine hereditary zinc deficiency, lethal trait A46: An animal model of acrodermatitis enteropathica. Genomics 88:521-526. 